TEME, г. XLI, бр. 3, јул - септембар 2017, стр. 573-585

Претходно саопштење

DOI: $10.22190 /$ TEME1703573S

Примљено: 2. 5. 2016.

UDK 373-055.2(497.11 Niš)”1879/1941““

Ревидирана верзија: 26. 11. 2016.

Одобрено за штампу: 15. 6. 2017.

\title{
ХУМАНИТАРНА И ВАСПИТНООБРАЗОВНА УЛОГА ЖЕНСКЕ ПОДРУЖИНЕ И ЊЕНЕ ЗАНАТСКЕ ШКОЛЕ У НИШУ ОД ОСНИВАЫА ДО ПОЧЕТКА ДРУГОГ СВЕТСКОГ РАТА
}

\author{
Мирјана Стакић $^{1^{*}}$, Слађана Видосављевић ${ }^{2}$ \\ ${ }^{1}$ Универзитет у Крагујевцу, Учитељски факултет у Ужицу, Ужице, Србија \\ ${ }^{2}$ Универзитет у Приштини, Косовска Митровица, \\ Учитељски факултет, Лепосавић, Србија \\ *mirjanastakic073@gmail.com
}

\begin{abstract}
Апстракт
У раду применом историјске методе и анализом педагошке документације испитујемо хуманитарну и васпитнообразовну улогу Нишке женске подружине и њене занатске школе од оснивања до почетка Другог светског рата. Подружине су представљале хуманитарне организације које су се бринуле о заштити жена и њиховом праву на просвећивање. Нишка подружина основана је после ослобођења од Турака, почетком 1879. године, као огранак Београдског женског друштва и непосредно је учествовала у оснивању и раду Женске занатске школе у Нишу (основане 1883. године). Жене су се током школовања оспособљавале за вез, израду белог рубља и хаљина. И поред минималне заступљености општеобразовних предмета, Нишка женска подружина и њена занатска школа су својим активним хуманитарним и васпитнообразовним деловањем омогућиле организовано институционално васпитање и образовање припадница женског пола. Ученице које су завршиле ову школу могле су да обављају занатске послове и тако добиле могућност да активно, заједно са мушкарцима, учествују у друштвеном животу Србије у првој половини XX века.
\end{abstract}

Кључне речи: Београдско женско друштво, Нишка женска подружина, Нишка женска занатска школа, васпитнообразовна и хуманитарна делатност. 


\title{
HUMANITARIAN AND EDUCATIONAL ROLE OF FEMALE COMMUNITY OF NIŠ AND ITS TRADE SCHOOL FROM ITS ESTABLISHING UNTIL THE BEGINNING OF SECOND WORLD WAR
}

\begin{abstract}
In this paper, by applying historical methods and the pedagogical documentation analysis, we examine the humanitarian and general educational role of the Female community of Niš and its trade school since its establishment until the beginning of World War II. The community of Niš was established after the liberation from the Turks at the beginning of 1879 , as a branch of the Female community of Belgrade. The communities represented humanitarian organizations that took care of the protection of women and their rights to enlightenment, and were directly involved in the establishment and operation of the Women's Trade school of Niš (founded in 1883). Women were more able to bond, to make lingerie and dresses during education. Despite the minimal representation of general subjects, the Female community of Niš and its trade school enabled organized institutional education of members, meaning women, through their active humanitarian and general educational operation. The female students who finished this school, were able to perform handicraft work and thus got the opportunity to, actively along with men, participate in the social life of Serbia in the first half of the twentieth century.
\end{abstract}

Key words: $\quad$ Female community of Belgrade, Female community of Niš, Women's Trade school of Niš, educational and humanitarian activities.

\section{УВОД}

За српско друштво, нарочито за образовање, важну улогу имале су бројне хуманитарне организације које су деловале у Србији од средине седамдесетих година XIX века. Њихова делатност премашивала је оквире хуманитарне помоћи. Многе од њих, попут Друштва Светог Саве, Женског друштва Београда, Друштва „Краљ Дечански”, Завода за српску сирочад, основале су у оквиру својих интерната вечерње, основне, недељно-празничне и женске раденичке школе. Њихов основни циљ био је рад на националном, хуманом, привредном и просветном пољу.

Услови за институционално школовање женске деце у Србији у XIX веку настали су 1846. године, када је издата Уредба владе „Устројеније девојачких училишта", којом су одређени задатак, организација и садржина женских школа (Ћунковић, 1971). Видосављевић указује на то да су велику улогу у практичном спровођењу Уредбе, односно „отварању занатских школа за женску децу”, имала женска удружења (Видосављевић, 2016, стр. 354). Године 1875. група просвећених жена из Београда удружила се да би повела рачуна о збрињавању сиромашне женске деце, о образовању домаћица и мајки. Основале су, под покровитељством кнегиње Наталије, „Женско друштво”. Милић истиче да им је једна од првих акција била отварање Прве женске раденичке школе 
намењене школовању сиротих девојака за „шваље, кроиље, везиље и ткаље” (Милић, 1998, стр. 412).

Оснивање прве женске занатске школе у Београду отворило је могућности да се и у другим градовима Србије оснују школе сличнога типа. Оне су имале велику улогу у побољшању социјалног положаја жене, чија је маргинализованост „била последица патријархалног односа и конзервативног гледања на њену улогу и место у друштву” (Видосављевић и Стакић, 2015, стр. 162). Једна од таквих школа била је и Женска раденичка занатска школа у Нишу, коју је основала Нишка женска подружина (у даљем тексту: Подружина). Њихова хуманитарна и васпитнообразовна делатност везује се за почетке успостављања институционалног стручног образовања жена на југу Србије, тему која је недовољно обрађена у савременој литератури, осим спорадичних истраживања (Видосављевић, 2016; Видосављевић и Стакић, 2015; Ђуровић и Вучковић, 2013; Милић, 1998; Лилић, 2003; Стефановић, 2011).

\section{ОСНИВАЊЕ И РАД НИШКЕ ПОДРУЖИНЕ И ЖЕНСКЕ РАДЕНИЧКЕ ШКОЛЕ}

У Нишу су после ослобођења Ниша 1878. године створени услови да се, уз помоћ Београдског женског друштва, 23. 1. 1879. године формира удружење жена под називом „Женска подружина Ниша”. Подружина се у почетку издржавала од чланарине и добровољних прилога. Један од првих резултата њеног рада био је оснивање Женске раденичке занатске школе 1883. године. Школа је припремала девојке за израду веза, белог рубља и хаљина (Лилић, 2003). У њој су били заступљени и стручни и општеобразовни предмети, те и практичан рад.

Прва председница Подружине у Нишу, по истраживањима Лилићеве, била је Анка Павловић, жена тадашњег среског начелника Косте Павловића. Међу оснивачима је и Јелена Рашић, жена познатог нишког националног радника Николе Рашића. Зграда Подружине и њене Женске школе најпре је била у Улици Француске републике, затим је пресељена у Просветну улицу, а од 1904. године је у Дворској улици, у згради коју је касније Подружина купила за 12.000 динара (Лилић, 2003).

За време српско-бугарског рата из 1885. године, Првог балканског рата и Другог балканског рата, Подружина је организовала болницу за лечење и негу рањеника (Миловановић, 1984, стр. 129). Услед ратних прилика, Женска занатска школа прекинула је рад 1915. године. Поново је почела са радом 1919. ангажовањем нове управнице Јелене Петровић (Стефановић, 2011).

Извештај о раду Подружине за 1920. годину показује да су у току 1914. и 1915. чланице, заједно са Београдским женским друштвом, 
које се у Нишу налазило после евакуације Београда, помагале у војној болници. Под надзором Управе Подружине, за војне потребе, радило се и за Црвени крст, Народну одбрану и Министарство војно. За време Бугарске окупације рад Подружине скоро да је престао, да би се наставио после ослобођења, 1918. године (Извештај о раду Нишке женске подружине за 1920. годину, 1921).

\section{РАД НИШКЕ ПОДРУЖИНЕ И ЊЕНЕ ЖЕНСКЕ ЗАНАТСКЕ ШКОЛЕ ИЗМЕЂУ ДВА СВЕТСКА РАТА}

После Ослобођења и стварања Краљевине Срба, Хрвата и Словенаца 1918. године, по већим варошицама ничу женске занатске школе. Велики допринос у њиховом оснивању дала су женска удружења као што су „Београдско женско друштво и њене подружине”, „Коло српских сестара”, „Женско друштво Српкиња”. Министарство трговине и индустрије, схватајући значај женских стручних школа, отпочиње са обнављањем уништених школа и оснивањем нових, уз помоћ женских удружења (Видосављевић, 2016, стр. 356). Донет је и Закон о женским занатским школама (Закон за занатске, женске занатске и средње техничке школе, 1922).

После ослобођења Ниша, школска зграда Женске раденичке школе је од 1. 10. 1918. године поново претворена у зграду за војне потребе и то је трајало све до августа 1919. године, када је враћена на коришћење Подружини и њеној Женској раденичкој школи (Димић, 1967).

У послератном периоду чланице Подружине посебну пажњу посвећују раду у болници, о чему сведочи и писмо захвалности које је управник болнице др Душан Радојковић упутио Управи Подружине:

\footnotetext{
„Дивим се пожртвовању чланицама Нишке Подружине око оснивања болнице испред непријатеља, аероплана, стварању угодне болнице од ничега јер је непријатељ у повлачењу све однео и разрушио" (Извештај о раду Нишке Женске подружине за 1920. годину, 1921, стр. 6).
}

Извештај о раду Подружине за 1920. годину показује да је управа Подружине састављала Одборе за дочек војске и прихват рањеника и све школске машине за шивење ставила на располагање Шивари Војног министарства. После преузимања школске зграде од војних власти, приступила је поправљању зграде и набавци основног инвентара. Захваљујући заузимању окружног начелника Вилдовића код Министарства трговине и индустрије, купљено је шест машина за шивење и рад школе је поново отпочео октобра 1919. године. Организована је настава у два разреда: првом и четвртом, са 44 ученице. Школска 1919/20. година показала се успешном јер су све ученице прешле у старији разред. Већ наредне школске године школа је 
имала 120 ученица и три разреда: први, други и пети (Извештај о раду Нишке Женске подружине за 1920. годину, 1921).

Уредбом Министарства трговине и индустрије о Женским занатским школама (1921) назив Женских раденичких школа промењен је у Женске занатске школе. Са новим Законом о женским занатским школама (1922), Женска занатска школа у Нишу постала је полудржавна, стручне наставнице исплаћивало је Министарство трговине и индустрије, док је друге плате, награде за хонорарне часове и материјалне трошкове сносила сама Подружина. Извештај о раду за 1923. годину показује да чланице Подружине да би могле да покрију материјалне трошкове, поред чланских улога, организују и бројне забаве, представе, концерте и изложбе. Успеле су да сакупе средства у висини од 40.000 динара за доградњу учионица и да у готовом остваре приход за 1923. годину - 22.496 динара (Извештај о раду Нишке Женске подружине за 1923. годину, 1924).

Поменути извештај показује и да се број ученица у Нижој и Продужној школи у Нишу повећавао, а како у школи није било довољно учионица, приступило се доградњи нове. По завршетку радова, организован је летњи курс кројења, који је похађало 100 жена и девојака. Сав трошак поднело је Министарство трговине и индустриje. Женска занатска школа у школској 1923/24. године има 200 ученица и 5 стручних наставница (Извештај о раду Нишке Женске подружине за 1923. годину, 1924).

Подружина је учествовала и у набавци мантила, ципела и чарапа за своје ученице. Угостила је 1923. године Управу и Женску занатску школу из Охрида, а нешто касније и из Цариброда. Активно је учествовала у Женском покрету, који се манифестовао радом Југословенског женског савеза. На Конгресу Женског савеза у Београду учествовала је чланица Кристина Бошковић и нарочито се заузела у решавању Инвалидског питања. Подружина је имала представнике и на конгресима Женског савеза у Загребу и Љубљани (Извештај о раду Нишке Женске подружине за 1923. годину, 1924).

И у наредним годинама настављена је сарадња са хуманитарним удружењима. Извештај о раду за 1925. годину показује да су чланице Подружине дежурале у друштвеном Обданишту, сакупљале прилоге за Црвени крст. Плодотворна је сарадња и са Пожаревачком женском подружином, из чега је настала идеја о оснивању ћилимарског курса. Ангажована је Пироћанка Јелена Владисављевић за

\footnotetext{
${ }^{1}$ Доношењем Закона о Женским занатским школама (1922), Женске занатске школе могле су бити: државне (које ће се оснивати у већим градовима), полудржавне (које ће се оснивати као установе Министарства трговине и индустрије, с једне стране, и женских удружења, са друге стране) и приватне (које ће се отварати где се за то укаже потреба). Према врсти, школе су се делиле на: ниже, продужне и више.
} 
наставницу. Управа Подружине помогла је оснивање радионице за израду пиротских ћилима у Казненом заводу и основала је и радионицу при својој згради (Извештај о раду Нишке Женске подружине за 1925. годину, 1926).

У Нишу је јула 1926. године велика поплава оштетила зграду Женске занатске школе. Подружина је очекивала помоћ од општинских власти. Када је схватила да ће она изостати, Управа се, по истраживањима Лилићеве, марта 1928. године обратила за помоћ Министарству трговине и индустрије. Захтев је одбијен, а чланице су, уз помоћ донатора и добровољних прилога, срушиле стару школску зграду и изградиле нову. Школа, или како су је звали „Дом са пет учионица и становима за управитеља, председника Подружине и помоћног радника", подигнута је у Улици 7. јула бр. 8 (Лилић, 2003, стр. 24). Рад у новој згради отпочео је избором наставника на седници Обласног одбора октобра 1928. године. За наставнике су изабране: Драгиња Стоиљковић из Ниша, за вез; Јелена Николић из Ниша, за хаљине; Босиљка Ђорђевић из Ниша, за хаљине; Зорка Јовић из Лесковца, за бело рубље, Радмила Антић из Приштине, за вез. Хонорарни наставник Пера Лукић предавао је Српски језик и Рачун (Лилић, 2003).

Уписница за 1930-1933. годину показује да школске 1929/30. године, у свих пет разреда, наставу похађа 81 ученица. Међутим, на завршни испит 25. 6. 1930. године, под председништвом Катарине Гирић и већег броја чланица Подружине, изашло је само 60 ученица, остале су у току школске године напустиле школовање - због болести, пресељења, искључења због лошег владања... (Уписница за 1930-1933, 1933).

Уписница показује да је већ наредне године, школске 1930/31, у I разред уписано 48 ученица, у II - 23, III - 30, у IV - 17 и V - 11, свега 129 (Уписница за 1930-1933, 1933). И према истраживањима Стефановића, број ученица се континуирано увећавао, о чему говори и податак да је у периоду 1919-1930. године наставу похађало „укупно 1.153 ученица" (Стефановић, 2011, стр. 162).

Законом о подели Краљевине на управна подручја (1929), ниже женске стручне школе прешле су у надлежност Бановина. Нови проширени Закон о Женским занатским школа (1932) дефинисао је као задатак Женских занатских школа да ученицама дају потребну општу и стручну спрему и оспособе их за самосталан рад у њиховом занату. Школе стоје под врховним надзором Министра трговине, а под надзором Бана (Закон о Женским занатским и женским стручним учитељским школама, 1932), и по рангу одговарају непотпуним средњим школама са нижим течајним испитом. Јовић истиче да је доношењем новог закона и Наставни план и програм Женске занатске школе у Нишу за школску 1932/33. годину претрпео измене (Јовић, 1936). 
Школа је по новом Наставном плану и програму отпочела са радом школске 1932/33. Анализом Записника са седница Наставничког већа у периоду 1930-1937. године утврдили смо да су стручне учитељице предавале и опште предмете, а неки предмети нису уопште били заступљени. У Првом приправном разреду, поред редовне стручне наставе, учитељица Босиљка Ђорђевић предавала је и Српскохрватски језик, Рачун и Гимнастику. Нису били заступљени Земљопис, Веронаука и Декоративно цртање. У Другом приправном разреду учитељица Драгиња Стоиљковић, поред стручне наставе, изводила је наставу из Српскохрватског језика, Рачуна и Гимнастике, а није била заступљена настава из области историје, земљописа, веронауке и декоративног цртања. У Првом стручном разреду учитељица Зорка Јевтовић, поред стручне наставе, изводила је наставу из Српскохрватског језика, Занатске калкулације, Хигијене, Познавања робе са домаћинством и Гимнастике. Није било наставе из области историје, земљописа, веронауке и декоративног цртања. У Другом стручном разреду учитељица Надежда Видановић, поред редовне стручне наставе, држала је наставу из Српскохрватског језика, Занатске калкулације, Познавања робе са домаћинством, Хигијене и Гимнастике. Нису били заступљени: Историја, Земљопис, Веронаука и Декоративно цртање. У Трећем стручном разреду (Атељеу) стручна учитељица Јелена Николић, поред Конфекције одела, подучавала је Израду луксузног белог рубља. Нису били заступљени Српскохрватски језик и Декоративно цртање (Записник са седнице Наставничког већа Женске занатске школе од 1930-1937, 1937).

Закон о Женским занатским школама из 1932. године једним делом аката односио се и на рад женских подружина. Управа Нишке подружине је маја 1933. године одржала главну скупштину на којој је изабрана нова управа. За председницу је поново изабрана Катарина Гирић, а за потпредседнице Драга Димић и Зора Андоновић (Записник са седнице Наставничког већа Женске занатске школе 19301937, 1937). На основу сачуваних извештаја о раду, евидентно је да Женска занатска школа није имала посебан школски одбор, већ је Управа Подружине вршила дужност и Школског одбора. У првом полугодишту школске 1934/35. године, у Женској занатској школи формиран је Школски одбор и Школски фонд. Школски одбор чиниле су: председница Одбора Катарина Гирић, истовремено и председница Женске Подружине у Нишу, и чланице Драга Динић, Зорка Старчевић, Николица Васић и Јелена Николић. Школски фонд чиниле су: председница Драге Динић, секретар Јелисавета Миловановић и чланице Никица Васић и Босиљка Ђорђевић, управитељице Женске занатске школе (Записник са седница Школског одбора Женске занатске школе у Нишу 1934-1944, 1944).

У школску 1935/36. годину уписане су 192 ученице и уводи се настава у две смене. Први и Други приправни и Први стручни разред 
имали су по два одељења, а Други стручни и Атеље по једно одељење. Стручне учитељице, поред разредног старешинства и стручне наставе, држале су и опште предмете. У Првом приправном разреду разредне старешине биле су: Ружица Пешић и Савета Стаменковић, а у другом: Босиљка Ђорђевић и Софија Миловановић. У Првом стручном разреду разредне старешине биле су: Драгиња Стоиљковић и Зорка Јевтовић, а у Другом Надежда Видановић. У Атељеу разредни старешина била је Јелена Николић (Записник са седнице Наставничког савета Женске занатске школе од 19. 9. 1935, 1935).

Сачувана документација показује да су се, поред повећања броја ученица и организованијег рада, појавили и проблеми у односу ученице-учитељице, као и проблеми у самом Наставничком савету. Од укупно 192 ученице, школу су напустиле 23, 4 су понављале разред, а 43 су полагале разредни испит. Само 122 ученице са успехом завршавају наставну годину (Записник са седнице Наставничког савета Женске занатске школе од 19. 9. 1935, 1935).

Банска управа је, у складу са Законом о женским занатским школама (1932), имала ингеренције да премешта стручне учитељице у Женску занатску школу у Нишу и поставља их тамо. Позивајући се на наведене слабе резултате у школској 1935/36. години, донела је решење о премештењу пет стручних учитељица. Записник са седнице Наставничког савета из 1936. године показује да су премештене учитељице које су више година радиле у Женској занатској школи: Босиљка Ђорђевић, која је истовремено била и вршилац дужности управнице школе, премештена је у Крушевац, Јелена Николић и Надежда Видановић у Књажевац, Софија Миловановић у Ћуприју и Зорка Јовановић у село Краљево (Записник са седнице Наставничког савета Женске занатске школе од 4. 9. 1936, 1936).

Истим решењем постављене су стручне приправнице: Десанка Димитријевић из Сврљига и Косара Нешић из Сењског Рудника; стручне учитељице Даница Николић и Јелена Станковић из Крушевца и Лепосава Ферфеловић из Јагодине. Другим решењем постављени су хонорарни наставници: са завршеним Филозофским факултетом Загорка Станковић и Добрила Костић Ковић за општеобразовне предмете; Живка Јањушевић за наставника гимнастике и Вермир Љубомир, академски сликар, за декоративно цртање (Записник са седнице Наставничког савета Женске занатске школе од 4. 9. 1936, 1936), тако да су школске 1936/37. године у школи заступљени сви наставни предмети.

И у том периоду, управа Нишке подружине испуњавала је дужности према Женској занатској школи, помагале су и градске структуре и добротвори. Извештај о раду за 1938. годину показује да је Подружина у току 1937/38. добила помоћ од Градског поглаварства Ниша у висини од 5000 динара и неколико хиљада динара од добротвора. Стање Касе Подружине на крају 1938. године износило 
је: приход 33.603 динара, расход 25.409 и чист приход 8149 динара (Извештај о раду Нишке Женске подружине за 1938. годину, 1939).

Управа Подружине је у току 1937/38. године помагала градским хуманитарним и патриотским организацијама, као што су Коло српских сестара, Пододбор „Српска мајка”, Друштво „Књегиње Љубице”, Друштво „Књегиње Зорке”, Обласни одбор друштва Црвеног крста, „Јадранска стража”, „Југословенска унија за заштиту деце”. И према Извештају о раду за 1939. годину, настављена је сарадња са многим организацијама и удружењима: чланице су на молбу Моравског бановског Одбора друштва „Црвеног крста” прикупљале добровољне прилоге; на апел Соколске жупе прикупљале прилоге за чехословачке избеглице; на молбу Секције за Моравску бановину Југословенске уније за заштиту деце и младежи, приликом прославе дечје недеље прикупљале добровољне прилоге (Извештај о раду Нишке Женске подружине за 1939. годину, 1940).

Према сачуваном Записнику са седнице Наставничког савета, школске 1937/38. године уписано је 176 ученица, а 151 са успехом завршава школску годину. Школа је имала 8 одељења и 5 разреда. Наставу изводи 10 стручних учитељица и 7 хонорарних наставника (Записник са седнице Наставничког савета Женске занатске школе, 1938).

Записник са седнице Наставничког савета из 1940. показује кадровску структуру школе. Као стручне учитељице запослене су: Јелена Николић (у школи је од 1919); Ружица Пешић (од 1925); Драгиња Стоиљковић (од 1926); Зорка Јевтовић (од 1928); Надежда Видановић (од 1932); Јелисавета Стаменковић (од 1935); Јелена Станковић (од 1936); Драга Голубовић (од 1936); Десанка Димитријевић (од 1936) и Лепосава Јовановић (од 1936). Као хонорарни наставници радили су: Даница Вељковић (Српскохрватски језик - 3 часа недељно); Владимир Крајтер (Рачуница - 3 часа недељно); Љубомир Вернер (Декоративно цртање - 15 часова недељно); Александар Тугаринов (Веронаука - 7 часова недељно); Живка Јанушевић (Гимнастика - 7 часова недељно); Раиса Кусњецова (Хигијена - 3 часа недељно) и Миливоје Покорни (Певање - 3 часа недељно) (Записник са седнице Наставничког савета Женске занатске школе, 1940).

Број уписаних ученица се, према подацима из наведеног записника, смањивао, а опадао је и број сталних стручних учитељица и хонорарних наставника. Тако су школске 1938/39. године уписане 164 ученице, са којима ради 7 стручних учитељица и 5 хонорарних наставника. Школске 1939/40. године било је 160 уписаних ученица (Записник са седнице Наставничког савета Женске занатске школе, 1940).

Школске 1940/41. (1. 4. 1941) прекинут је рад Женске занатске школе у Нишу. Лилић истиче да је петог априла наведене године наложено свим женским школама да спакују уписнице, овогодишње прозивнике, благајничке књиге, овогодишње деловоднике, уложене 
књижице са школским печатима; а наставницима је наређено да остану у местима службовања и ставе се на располагање месним властима (Лилић, 2003). Следећег дана нападнута је Југославија, а 18. априла 1941. године је капитулирала. Рад у школама је отежан због ратних прилика, а у многима и потпуно престао. Наредбом окупаторских војних власти од 9. 5. 1941. забрањен је рад Подружине у Нишу (Ђуровић и Вучковић, 2013). ${ }^{2}$

\section{ЗАКЉУЧНА РАЗМАТРАЬА}

Подружина је, као један од оснивача Женске занатске школе, својим хуманитарним и васпитнообразовним деловањем значајно утицала на друштвени живот не само у Нишу и на југу Србије већ и у Србији уопште. Реч је о периоду који је везан за почетке институционалног средњошколског образовања жена у Србији и одсликава све тешкоће са којима се суочавало његово успостављање: недостатак стручног кадра и материјалних средстава, осипање ђака... Делатност Подружине зато обједињује област васпитнообразовног са хуманитарним деловањем, јер је обезбеђивање материјалих средстава за рад школе захтевало ентузијам и организовање бројних добротворних акција.

Будући да Женске занатске школе представљају и претече нашег савременог стручног образовања, сматрамо да је потребно: 1) истражити рад занатских школа у Србији у дијахроној и синхроној перспективи, у циљу компаративне анализе наставних програма и испитати заступљеност, однос и број часова стручних и општеобразовних предмета; 2) актуелизовати тему са аспекта родне равноправности.

Компаративна анализа наставних програма могла би да укаже и на неке од потенцијалних слабости нашег савременог стручног образовања. Рецимо, Историја и Географија су као предмети биле заступљене у свим разредима некадашњих занатских школа (Јовић, 1936, стр. 2), посебна пажња посвећивала се учењу матерњег језика, што показује да опште образовање није било занемарено. Поред васпитнообразовне улоге, стицање дипломе занатске школе у патријархалном србијанском друштву финансијски је оснаживало жене. Оне су, кроз бављење занатом, имале могућност да зарађују и не буду у економски подређеном положају. Актуелизацији теме са аспекта родне равноправности доприноси и сазнање да је у Србији још средином седамдесетих година XIX века постојала свест о значају школовања припадница женског пола.

\footnotetext{
${ }^{2}$ Рад у Женској занатској школи у Нишу под окупаторском влашћу „отпочео је 16. 5. 1941. године" (Лилић, 2003, стр. 52).
} 


\section{ЛИТЕРАТУРА}

Видосављевић, С. (2016). Почеци институционалног стручног васпитања и образовања женске деце у Србији [Institutional vocational education of female children in Serbia]. Зборник Матице српске за друштвене науке, бр. 155-156, 353-361.

Видосављевић, С., Стакић, М. (2015). Прва призренска и нишка учитељица Анастасија - Наста Димитријевић (1816-1886) [First Prizren and low teacher Anastasija-Dimitrijevic (1816-1886)]. Баштина, бр. 39, 161-169.

Димић, Љ. (1967). Културна политика Краљевине Југославије 1918-1941. [Cultural policy of the Kingdom of Yugoslavia 1918-1941]. Београд: Стубови културе.

Ђуровић, Љ., Вучковић, М. (2013). Женска подружина - Ниш (1879-1941) [Women branch - Niš (1879-1941)]. Водич историјског архива Ниш, бр. IX/2, 270-271.

Јовић, М. (1936). Збирка законских и административних прописа за Женске занатске

школе, књига 1, Наставни план и програм за Женске занатске школе [Collection of legal and administrative rules for Women handicraft school, book 1, Curriculum for Women vocational schools]. Ниш: „Св. Цар Константин”.

Лилић, Б. (2003). Стручна школа „Филип Кљајић” - Ниш (1883-2003) [Vocational school „Filip Kljajić” - Niš (1883-2003)]. Ниш: ДИГП „Просвета".

Милић, Д. (1998). Жена у привреди Србије у XIX веку [Woman in the economy of Serbia in the XIX century]. У: М. Дашић и П. Пијановић (Ур.): Зборник радова са Десетог конгреса историчара Југославије (411-420). Београд: Савез историчара Југославије

Миловановић, М. (1984). Историја Ниша, књига I, Школство у Нишу и околини [History of Nis, Volume I, Education in Nis and surroundings]. Ниш: Градина и Просвета.

Стефановић, М. (2011). Женска занатска школа Нишке женске подружине [Female Vocational School Niške women subsidiaries]. У: М. Стефановић и Д. Јевтић (Прир.), Нишки лексикон [Nice lexicon] (стр. 162). Београд: ЈП Службени гласник/Град Ниш.

Ћунковић, С. (1971). Школство и просвета у Србији у ХІХ веку [Schooling and education in

Serbia in XIX century]. Београд: Педагошки музеј у Београду.

\section{ИЗВОРИ (АРХИВСКА ГРАЋА И ЗАКОНИ)}

Записник са седнице Наставничког савета Женске занатске школе од 19. 9. 1935. [Minutes of the meeting of the Teachers Council of Women craft school from 19. 9. 1935], Историјски архив Ниша, Књ. 1 (1935).

Записник са седнице Наставничког савета Женске занатске школе од 4. 9. 1936. [Minutes of the meeting of the Teachers Council of Women craft school from 4. 9. 1936], Историјски архив Ниша, Књ. 1 (1936).

Записник са седнице Наставничког већа Женске занатске школе од 1930-1937. [Minutes of the meeting of the Women's Council of Teachers of vocational schools 1930-1937], Историјски архив Ниша, књ. 1 (1937).

Записник са седнице Наставничког савета Женске занатске школе [Minutes of the meeting of the Teachers Council of Women craft school], Историјски архив Ниша, књ. 5 (1938). 
Записник са седнице Наставничког савета Женске занатске школе [Minutes of the meeting of the Teachers Council of Women craft school], Историјски архив Ниша, књ. 6 (1940).

Записник са седница Школског одбора Женске занатске школе у Нишу 1934 1944. [Minutes of the meetings of the school board Women's Vocational School in Nis 1934-1944], Историјски архив Ниша, Књ. 3 (1944).

Извештај о раду Нишке Женске подружине за 1920. годину [The report on the work of low female community for 1920]. Часопис Женског друштва и његових подружина Домаћица, Београд (1921).

Извештај о раду Нишке Женске подружине за 1923. годину [The report on the work of low female community for 1923]. Часопис Женског друштва и његових подружина Домаћииа, Београд (1924).

Извештај о раду Нишке Женске подружине за 1925. годину [The report on the work of low female community for 1925]. Часопис Женског друштва и његових подружина Домаћища, Београд (1926).

Извештај о раду Нишке Женске подружине за 1938. годину [The report on the work of low female community for 1938]. Часопис Женског друштва и његових подружина Домаћица, Београд (1939).

Извештај о раду Нишке Женске подружине за 1939. годину [The report on the work of low female community for 1939]. Часопис Женског друштва и његових подружина Домаћииа, Београд (1940).

Уписница за 1930-1933. годину, Женска занатска школа у Нишу [Registration Form for 1930-1933. year, Women's Vocational School in Nis], Историјски архив Ниша, Књ. 54 (1933).

Закон за занатске, женске занатске и средње техничке школе [Law on handicraft, women's handicraft and technical secondary schools], Службене новине Краљевине Срба, Хрвата и Словенаца. Бр. 105, Београд (1922).

Закон о подели Краљевине на управна подручја [The law on the division of the Kingdom into administrative areas], Службене новине Краљевине Југославије. Бр. 232, Београд (1929).

Закон о Женским занатским и женским стручним учитељским школама [Law on Women's crafts and women's professional teacher training schools], Службене новине Краљевине Југославије. Бр. 82, Београд (1932).

Уредба Министарства трговине и индустрије о Женским занатским школама [Regulation of the Ministry of Trade and Industry on women's vocational schools], Службене новине Краљевине СХС. Бр. 195, Београд (1921). 


\title{
HUMANITARIAN AND EDUCATIONAL ROLE OF FEMALE COMMUNITY OF NIŠ AND ITS TRADE SCHOOL FROM ITS ESTABLISHING UNTIL THE BEGINNING OF SECOND WORLD WAR
}

\author{
Mirjana Stakić ${ }^{1}$, Slađana Vidosavljević ${ }^{2}$ \\ ${ }^{1}$ University of Kragujevac, Teachers Training Faculty, Užice, Serbia \\ ${ }^{2}$ University of Priština, Kosovska Mitrovica, Teachers Training Faculty, Leposavić, \\ Serbia
}

\section{Summary}

Since the establishment of the Women's Trade school in NiŠ, in 1883, UNTIL April 1, 1941, when it stopped working due to the outbreak of the Second World War, during a period of fifty-eight years, the Female community of Niš actively took care of its survival, the organization of work, quality of teaching and extracurricular activities. Founded as a women's humanitarian organization, whose members are worried about the rights and education of women, the community immediately was involved in the very beginnings of the institutional secondary education of women in Serbia. As direct founders of the Women's Trade school, the members of community provided funds for the purchase of school buildings in Niš, during the war years of World War I, turned into a military hospital. In that period, and in the early postwar years, the work of the community was carried out for military purposes and needs of the population in Niš. The members dedicated themselves to work in hospitals, school sewing machines made available Šivaram military ministry. After taking over the school building from the military authorities, the efforts of the community were directed towards its repairs and the procurement of basic school inventory, and to the normalization of teaching. Following the adoption of the Law on Women's Trade Schools (1922), this school in Niš had become a semi-state, because the Ministry of Trade and Industry payment of salaries to qualified teachers, while the Management of community had to take care of the school material costs and salaries and rewards for freelancers classes. Caring for the financial survival of the school meant for the members of the community that a number of humanitarian actions aimed at collecting funds and at ensuring conditions for the education of women had to be taken. In addition to regular membership dues, they, for this purpose, organized numerous entertainment, shows, concerts, matinees and exhibitions. In addition to care abou thet school, the community collaborated with numerous charitable women's organizations and associations, and actively participated in numerous activities that were aimed at improving the lives of both the local population and marginalized groups, such as the action of opening a workshop for making rugs in penal institutions in Niš. The care of Women's Trade school meant that the Board of Community had to comply with all legal regulations and acts and to provide teaching staff who would provide students with the necessary general and professional education. Due to the lack of professional staff, during the thirties of the twentieth century many professional teachers taught general subjects, and some items, such as history and religion were not represented. Shedding the number of enrolled female students and the lack of permanent professional teachers and part-time workers at the school were constantly the problems of the community. Despite the problems, states managed to organize numerous actions, allocation of resources, so the classes were maintained regularly until the beginning of World War II. The humanitarian and educational role of the Women's Trade in Niš in institutional education and upbringing of women and improvement of the quality of life of the whole community shows a great strength and enthusiasm the members of the administration of a voluntary association of women, founded in 1879 , had and therefore, in many ways it represents the forerunner of modern informal women's associations and organizations. 